\title{
THE IMAGE OF ARAB IMMIGRANTS IN AMERICAN AND BRITISH PRESS: CRITICAL DISCOURSE ANALYSIS
}

\author{
Asst. Prof. Huda Abed Ali Hattab, Rasha khalil Ibrahim Fakhir \\ DOI: $10.37648 / \mathrm{ijrssh} . v 10 \mathrm{i} 02.009$ \\ Received:02 ${ }^{\text {nd }}$ January, 2020; Accepted:23rd January, 2020; Published: $14^{\text {th }}$ February,2020
}

\begin{abstract}
Social media has a salient role in the representation of Arab immigrants who fled from the continuity of wars in their countries which creates social economic, and political crises. This paper is a "critical discourse analysis" for investigatingthe image of Arab immigrants in Amercan and British newspapers from 2015 to 2018 . Accordingly, the paper adopts "Wodak \& Van Dijk" (2001) ideological analysis . Both quantitative and qualitative analysis are used to analyze the eight articles are chosen from both newspapers (New york post) and (The Daily Express).
\end{abstract}

\section{INTRODUCTION}

Europe and America have recently witnessed a record influx of migrants whose many belong to Middle East (Al Wekhian,2015: p.51 ).The conflicts factors is mainly beyond themigration process in the Middle East (Pew Research Center reports in 2016) . Alot of Muslim countries are rulled by dictators and royal families who often violate concepts of human rights and democracy (Khan, 2003:98). Thus, the middle east area has witnessed "Arab Spring"revolutions which spread including Egyptian, Libyan, and Yemeniregimes ( Al-Azzawi,2018:55).

This, in turn forced many people to emmigrate countries for European countries. On the Other hand, many Syrian and Iraqi peoples forced to migrate because of armed conflict against ISIS in their countries (Shaban, 2018:8) The inclusion of immigration polices within anti terrorism agendas resulted from series of terrorist attacks in western countries similar to the situation that occurred in the USA after 9/11 (Estevens ,2018:3). Concequently hostility discourse against Muslims, and especially Arabs is intensified opening the doors for systems of bigotry that is currently known as Islamophobia (Beydoun ,2018:50).

Immigrants represntations in western newspapers have motivated the present study to critically examine the image of Arab immigrants in American and British newspapers.

Accordingly,the study addresses the following researchquestions:

1- Does the image of Arab immigrants presented negatively or postively in the selected newspapers?

2- what are the ideological representation that are used 
to represent the Arab immigrants in the newspapers under investigation?

\section{LITERATURE REVIEW}

\subsection{Critical Discourse Analysis}

"Critical Linguistic" was early founded in 1979 by the linguist Fowler and his colleagues (weisse et al. , 2004:176). It based on Halliday's theory concepts of Systemic-Functional Linguistics . (Hanak, 2009:192).

"Critical linguistics" lacks the connection among language, power and ideology which could be better captured by " critical discourse analysis" (Mayr \& Machin , 2012:4). Though the mentioned difference, Many linguists think that both terms critical linguistics and critical discourse analysis can be used interchangeably.

" Critical discourse analysis" deals with language as being a social practice with concentrating on the context of language use. It is mainly concerned with the connection between language and power. (Wodak, 2001:2).The developments in this field can be traced to the pioneering works of the three linguists, Fairclough , Van Dijk, and Wodak (Weiss \& Wodak, 2003:35) .

Fairclough (1995: 132, 133) stated that " By critical discourse analysis I mean discourse analysis which aims to systematically explore often opaque relationships of causality and determination between (a) discursive practices ,events and texts, and (b) wider social and cultural structures, relations and processes; to investigate how such practices, events and texts arise out of and are idologically shaped by relations of power and struggle over power; and to explore how the opacity of these relationships between discourse and society is itself a factor securing power and hegemony".

Meanwhile Van Dijk (2001) defines it as that "type of discourse analytical research that primarily studies the way social power abuse, dominance, and inequality are enacted, reproduced, and resisted by text and talk in the social and political context. Thus, critical discourse analysts take explicit position to understand, expose, and ultimately resist social inequality " (p.352) .

Wodak (2001:2), as one of the pioneers in this field, think it is " concerned with analyzing opaque as well as transparent structural relationships of power, dominance and discrimination as manifested in language . " It aims at investigating the social inequality from critical perspectives, as it is expressed, signaled, , legitimized, and constituted by language use . (Ibid)

The target of critical discourse anlysis is to criticize the social inequality and injustice of dominated powerful groups in society. As fairclough has clarified that the term "critical" includes revealing the connections and reasons that are hidden and underlie texts . (Weiss \& Wodak , 2003:36,38)

Thus, Van Dijk (2001) suggests general notions to be investigated for "critical discourse analysis" that are dominance power, hegemony, class ideology, race gender , discrimintation, and institutions as well as social order .( Lester \& Paulsen, $2018: 60$ )

Critical discourse analysis approach has been criticized like to other fields in linguistics. Fowler (1996) criticized the uncontrolled methodologies of "critical discourse analysis" which drawn from a avariety of models in the social sciences. (Breeze, 2011: 502) . It contains different approaches that offers different modes of analysis such as Fairclough's "dialecticalrelational approach" , Van Dijk's "socio-cognitive approach", and Wodak's "discourse-historical approach". (Al-Saaidi \& Matrood,2018:69)

Therefore, it does not have a unitary theoretical framework , Obviously this will causea lack in coherence, unsystematic application of methods, indiscriminate mixing o incompatible concept, and so on . While many scholars in "Discourse analysis" likeFaircloughand Chouliaraki (1999);Wodak and Weiss (2002) agree that this openness upon a scope of various philosophical and sociological concepts implied that the field is strongly based. (Breeze , 2011: 502) .

Another point of criticism is that CDA explicit reliance is being placed chiefly upon the analyst's interpretation 
of the texts. Cameron (2001) suggests that the recipient's interpretation must be taken in to consideration, since discourse is interactive. (Paltridge, 2012:199)

Fowler (1996:7) stands against this criticism, he argues that discourse may be interpreted differently by different recipients, therefore there is no "fixed meaning" of textual interpretation.

Corpus approaches has been suggested to increase the quantative dimention since its samples are considerablly large and its methods ortechniques are more systematic. In addition, researches in this field proposed systematic functional linguistics for a more detailed linguistic analysis . (Paltridge , 2012:199) Consequently, CDA may be enhanced aganist the lack of sufficiently detailed and systematic textual analysis . (Breeze, 2011: 502-503)

\subsection{Ideology and Racism in Immigration Discourse}

Much of people discourse express ideologically based opinions. Thus, ideology is defined as "a systematic body of ideas, organized from a particular point of view." (Hodge and Kress,1993: 6).People learn most of their ideological ideas from other members in their group particularly from their parents. Later they 'learn' ideologies by exposing to a multitude of other forms of talk and text through watching television, reading text books at school, and the newspaper....etc.

According to (Fairclough and Wodak,1997) ideologies refer to "particular ways of representing and constructing society which reproduce unequal relations of power, relations of domination and exploitation." The dominanted ideologies are those of the powerful groups in society. (Shousha, 2010:9)

Van Dijk, T. (2000a) belived that ideologies arise from group conflicts and struggles and form the base for the social practices of group members . Thus, discrimination derived from racist ideologies,protest against nuclear wars based on pacifist ideologies, and anti pollutionactionsguided by ecological ideologies (.p.8)

Researchershold the view that ideologies are "basic systems of beliefs". Thus other specific beliefs may be organized and guided by them. Thus, many racist attitudes andprejudices are based on racist ideologies . So themes like, the relation between immigration and crime and their role in the labor market, and so on are controlled by ideologies (Ibid:14)

Racist ideologies is for instance represented by the current situation in America where anti-Muslim ideologies and xenophobic against muslim immigrants have grown rapidly. For a century and a half ,Muslim immigrants have been prohibited from becoming citizens and faceddiscrimination and dehumanization (Beydoun, 2018:20) .

Van Dijk (1991) showed that immigrants and minorities are portrayed as threat and a problem and are associated with conflict, violence, deviance ,crime, unacceptable and cultural differences . (Abdullah\& Mukundan, 2014: 33 )

In a study examined "critically the dominance inequality of the time magazine corpus about the Muslims." They found that Muslim community is portrayed negatively and Muslims are presented as terrorists and extremists. They stated that American magazine didn't show their direct intentions about any community, but indirectly by useing so many adjectives about Muslims in a negative sense. (Abdullah\& Mukundan, 2014: 44 )

Basically, they pointed that the overall strategy of most ideological discourse is the "positive self-presentation and negative other-presentation". It characterize the group conflict while interacting with opposed groups. According to (Wodak and Reisigl ,1999:181), Racism is "both an ideology of a syncretic kind and a discriminatory social (including discursive) practice that could be institutionalized and backed by the hegemonic social groups". It is also based on invariable of traits that are primarily rconnected with biological features, customs appearance, cultural practices,language, traditions, , or socially stigmatized ancestors.

These traits are implicitly and explicitly, directly or indirectly presented negatively which is related with 
hegemonic views.

The notion of biological race has been known Since late of 20th centur It is recognized as a cultural invention without any scientific basis . (Smedley,2017)

Van Dijk, T. (2000a) defined Racism "as a system of ethnic/racial inequality, reproduced by discriminatory social practices, including discourse, at the local (micro) level, and by institutions, organizations and overall group relations on the global (macro) level, and cognitively supported by racist ideologies".(p.41)

Consequently,the ideology of news reporting include more than the content and style of news reports.It imbues all aspects of news gathering, preparing the sources, and the organization of the professional activities of journalists (meetings, deadlines, etc).

Socialas well as Professional ideologies of journalists fundamentally judge who will be covered, who will be searched for, and whointerviewed, who listened to , or cited. Thus, the number of activities in the newspaper or on television mayfundamentally influenced by social actors and ideologically be based( Ibid:34)

\subsection{Previous Research Works}

Many contributions has been done in this field regarding power relations in society to clarify the ideologies that are produced or legitimized in certain discourse structures . (Rahimi \& Sahragard, 2006 :16)

1-Shousha 's research (2010) is an attempt to discover the Image of Arabs in American Press through the analysis of Newsweek and The Washington Post reports. The researcher used content and critical discourse analysis models to analyze the language of media to find out how Arabs were portrayed.

The study covered the period between 2001 and 2007 with specific focus on the period from the 17th of September 2001 till the 31st of December 2001. As for the attitudes of writers and their portrayed Arab image, it is a negative image in almost all articles .

The analysis of the articles elaberates the following linguistic features :thematic patterns, syntactic patterns , lexical choices, and the rhetorical devices, to clarify the dominant ideologies in the society and the unequal power relations that reflected badly on the negative image of Arabs.

As reflected from the themes discussed in the analyzed articles, no article focused on the portrayal of the ordinary Arab character. The concentration was on the relationships between the U.S. and its Arab allies (Saudi Arabia and Egypt), the description of the Arab regimes, the estimated role of the Arab countries in the war against terrorism and America's foreign policy in the Middle East.

The Arab regimes were criticized as their way of ruling their people affected their societies and led to the emergence of terrorism not inside their countries but directed to the outside world especially America and its interests.

Arabs are not collocated with negative words in the discourse analyzed; only Muslims are associated and collocated with terrorism. The lexical collocations are not responsible for the negative image of Arabs ; it is the whole discourse that does it for them.

2- Semaan's (2014) study internalize a guidance for scholars to show what has been published about Arab Americans . He examined the Stereotypes ,History, Conflict, and Cultural Identity of Arab Americans after 9/11. It shows the whole variety of scholar's studies that deals with this minority group.

It aims to facilitate future interdisciplinary approaches to search in this field. In addition, the reviews and the bibliographical informations provides general insight about the evolution of researching Arab Americans and what are the circumstances surrounding the scholarly interests in to this group.

3- A Content Analysis of Press Coverage of Migrant's Crisis inFive European Countries which was done by agroup of researchers in (2015) . The research examined how the press reported on migration crisis in 2014 and 2015 in two main patterns of news coverage . The first examined a lot of reporting news across 2014 and early 2015.

The second sample deals with a specific case of a week's reporting news in 18 April 2015 entitlled "boat 
disaster in the Mediterranean". The European states chosen for the analysis were the UK, Spain , Germany, Sweden, and Italy .

The analysis attempted to answer the following questions regarding the key sources in the coverage, the political parties are widly cited, the sending countries of refugees and migrants, the terms are generally used to describe them, the important themes mentioned in coverage, the reasons for hosting them, and the solutions to this crisis .

The researchers gathered a sample of 300 news reports to per country. Thus the overall total was 1500 news articles. The dominant news reports about asylum seekers and refugees emphasized the idea that migration represented a 'problem' and as a 'crisis' issue. Those reports showes a dehumanised image of migration by focusing merely on the increasing numbers of those migrants .

4-Within Van Dijk's (2000) framework, Al-Zubaidi \& Hassan (2018) the discoursal representation of Iraqi immigrants in several English and Arabic news channels from critical points of view. Twenty news subtitles has been taken from the English channels ' $\mathrm{NBC}$ and $\mathrm{ABC}$ ' and the Arabic channels 'Al Iraqia and Al Hurra'. Iraqi immigrant's image is examined with regard to five ideological perceptions and assumptions including "us vs. them", "ingroup vs. outgroup", "victims vs. agents", "positive selfpresentation vs. negative other-presentation", and "threat vs. non-threat".

The results showes that Iraqi immigrants are depicted negatively in English and Arabic news channels. The discourses of both channels are fulled with racistperceptions and ideologies towards Iraqi immigrants embodied the viewpoints of their owners. Besides, the two languages employ the same discourse and ideological categories in constructing the portrait of Iraqi immigrants in their news discourses

5- Critically Al-Saaidi \& Matrood (2018) have studied the portrayal of Iraqi refugees in social media discourse and its impact on EFL cultural awareness . This research provides a qualitative analysis of a news report entitled World 'ignoring Iraqi refugees' (2007) after the US-led invasion of Iraq .

It is taken from the British Broadcasting Corporation (BBC) and particularly from the internet website archive Using the referential, predicational, perspectivisation and intensification/mitigation strategies that are associated with the image of the social actors in the analysi. The analysis showes that media has a crucial role in the depiction of social actors in particular to the case of Iraqi refugees.

In addition media discourse has the effect on the development of the EFL cultural awareness and identifying the ideology-laden structures. This will develop the learners ${ }^{\text {ee }}$ awareness of the Western societies and ideologies towards Iraqis abroad. This is shown through the BBC news report which is neutral in representing its news as it shows a negative representation for the Dutch governmentes cruelty against the Iraqi refugees.

\section{METHODOLOGY}

The present study provides both ideological and linguistic analysis of the representation of Arab immigrants in the selected newspapers. The analytical categories relevant to the objectives and scope of this study are those of Wodak \& Van Dijk (2000:29) and Van $\operatorname{Dijk}(2000: 106)$ for "racist" and "anti-racist" immigration discourse. The study analysis will combine two deminsions of macro, and micro-level analysis.

The ideological assumptions underlying the discourse of immigration will be examined in the macro level. Vandijk (2000) defines topics as "sequences of macro propositions of a text." The selection of ideological topic involves any topic that contributes to the formation of positive and negative social representations of ingroup and out group (Van dijk , $2002: 101)$.

Racist discourse involves "Positive self representation and negative other representation" strategies. (Wodak \& van Dijk ,2000:29) Ideological discourse against minorities will govern produsing specific opinions such as keeping (Them) out of the country, the neighborhood, the job, etc. (Vandijk, 2002 :98)

On the other hand, anti racist discourse involves "positive other-presentation" strategy which expected 
to be found with humanitarian ideologies and sympathy towards immigrants ,e.g the horrors asylum seekers have lived through (Ibid:106,107 ).

Negative representations may be relevant for selfcritical discourse about the writers' people, institutions or country for violating basic rules, norms, principles of Human Rights, such as the norm that asylum seekers cannot be sent back, that innocent people should not be put in prison, and so on. Hence presupposes a split within the ingroup itself that the writer is not criticising himself, but criticising others in his group who violate human rights. (Ibid:107,108). It is worth mentioning that the researcher will focus on immigrants (Other) representation more than self-representation.

The linguistic analysis will be examined in the micro level by focusing on the following:

- "actor descriptions (categorization, descriptions ,attributes)";

- "rhetorical devices - metaphors, hyperboles, euphemisms";

-"implicitness, presuppositions";

-" argumentation (topoi, fallacies, counterfactuals)".

As for social actors are concerned, they are described as individuals or members of group by their first name or the name of the family as well as the name or the role of the group (Rahimi \& Sahragard: 2006,38). The representation of social actors in terms of identities and functions shared with others is categorization. (Leeuwen, 2013: 54,) Thus, the social actor may be categorized according their activety regarding their occupation or role in society (e.g, pianist, guardian ) or categorized in terms of what they are . (e.g, 'we', Japanese, young white thugs, the down town and up town immigrants, dark skinned black, poor, Muslim , immigrants, redhead, large moustaches,) (Ibid : 58,59)

Actors areevaluated and described in terms of ideologies, so members of in-group are described positively, while members as out-group are often described negatively . (Van Dijk, 2004, p. 17)

Actor description implies the use of 'categorization' through which people tend to be assigned to different groups .e.g,. asylum seekers are categorized in to "genuine" political refugees and "bogus" .(Rahimi\&Sahragard:2006,39)

On the other hand, actor description may include evaluative attributions ofpositive or negative traits (e.g. in the form of adjectives, prepositional phrases, appositions, conjunctional clauses, relative clauses, and participial clauses) (Reisigl \& Wodak: 2009,95 )

However the rhetorical devices as metaphor, hyperbole, euphemism are used for emphasising and de-emphasising meanings . (Van dijk,2002:109).In migration discourse, the metaphorical device is more persuasive than other devices. It is used to describe the unfavorable arrival of migrants in terms of their unstoppable threat to the destenation countries .(Rahimi \& Sahragard:2006,38)

In addition to "Hyperbole" device that is used for enhancing and exaggerating meaning. It is applied with reference to the statistical data for the number of migrants and the use of adjectives and adjectival phrase such as huge, enormous. (Al-Saaidi:2018, p.80) In the case of "Euphemisms", "negative opinions about immigrants could be indicated with avoidance as being described as bluntly prejudiced." For instance ,the use of the term "illegal invader" invoke a threat frame. ( Nowrasteh : 2017 )

There are other categories in the micro level like, implicitness, and presuppositions. Van Dijk suggests that discourses are "implicit" in the sense that much information is not expressed directly, but only understood to be implied ( (Hassan:2017,69).

Discourse meanings are almost inferable from sociocultural knowledge when the presupposition are mostly used to presupposed the truth when they are not established. (Rahimi\&Sahragard:2006,43)

Finally, argumentation are used for persuading addressees of the truth and normative rightness of claims for example when the Conservative speaker try to emphasize that asylum seekers break the laws and norms, or that poor ratepayers should not pay for able asylum seekers.( Reisigl and Wodak :2009,113)

Thus, argumentation is "the process of forming reasons, justifying beliefs, and drawing conclusions with the aim 
of influencing the thoughts and/or actions of others" (Nordquist :2019). Furthermore,Fallacies are defects that cause an argument to be invalid, unsound, or weak (Austin: 2019). Vandjik $(2002,112)$ thinks that the typical fallacy of racist discourse is generalised from single examples, as the claim that asylum seekers are lazy, or criminals. Thus, the aregument that immigration should be stopped since they may combine with financial burdens may be based fallacious conclusions. ( Rahimi \& Sahragard : 2006,42). Therefore,no evidence may be offered in this case to support the regumentation (Blackledge,2005:p.201) •

Finally aregumentation strategies include "Topos" which are content-related Warrants. Wodak presents a list of topos that were used in the analysis of arguments regarding discrimentation. A short general list of topoi includes: topos of danger/threat ,topos of Justice , topos of responsibility topos of advantage/usefulness,topos of humanitarianism, topos of definition/name interpretation, , topos of law/right, topos of culture, topos of abuse and topos of authority, topos of reality, topos of burdening/ weighting down topos of finance, topos of numbers, , and topos of history (Wodak:2017,p.33) (Wodak :2001,p.74).

Finally, (counterfactuals) are called invented scenarios that is presented as alteration to reality that is occured. Vandijk (2004) presents atypical expression as "what would happen, if ..." when the conservatives try to imagine what would be like if they were in asylum seekers situation.(Ibid:p.40)

The present study adopts a mixed analytical methodology . Both qualitative and quantitative analyses are employed in the analysis of British and American articles from a critical perspective. The table below puts together the model applied and the research questions within the study hypotheses:

\section{DATA ANALYSIS}

Following the analytical methodology presented previously, this part is a critical discourse analysis of the representation of Arab immigrants in articles taken from American and British newspapers namely, the New york post for American press and The Daily express for the British since 2015 to 2018 .

\subsection{CDA of the image of Arab immigrants in American newspaper (New York post)}

This part presents a CDA of extracts of four articles chosen from the websites of American newspaper (New york post).

\subsubsection{Extracts from New York Post Article (1) :}

"Why America will lead the way in resettling the refugees"

\section{Extract (1)}

"Europe has done a poor job of turning immigrants, especially from the Middle East, into Europeans. France, which (like the United States) has at least a nominal assimilationist ethos, has nonetheless failed tointegrate its large Muslim population, which now accounts for about 8 percent of the population".

\section{Extract (2)}

"Despite the claims of US anti-immigrant groups, America's immigrants quickly assimilate into the social and economic mainstream. There are many reasons for this — not least that virtually all Americans have foreign roots - but we also believe in the importance of assimilating newcomers quickly". 
A- The Ideological Analysis of Extract (1-2) which is illustrated in Table (4-1) below

\begin{tabular}{|l|l|l|l|}
\hline No. & Parts Selected & \multicolumn{2}{|l|}{ Macro analysis } \\
\hline $\mathbf{1}$ & $\begin{array}{l}\text { "Europe has done a poor job of turning immigrants, } \\
\text { especially from the Middle East, into Europeans" }\end{array}$ & Europeans & immi grant \\
& $\begin{array}{l}\text { Immigrants are portrayed positively here because the blame has been directed to (Us) the } \\
\text { Europiean countries because Muslim and Arab immigrants havenot got any apportunity } \\
\text { to integrae within the society. In addition they have faced an anti immigration voices as } \\
\text { well as the election of right-wing parties that are against migrant policy. }\end{array}$ \\
\hline $\mathbf{2}$ & $\begin{array}{l}\text { "the American people and our traditions of assimilating } \\
\text { newcomers will at least lead to better lives for those } \\
\text { Syrians" }\end{array}$ & $\begin{array}{l}\text { American } \\
\text { people }\end{array}$ & \multicolumn{2}{|c|}{ Syrians } \\
In this part, Both American people and Syrian immigrants are potrayed positively for \\
their ability to integrate well in the social and economic life .
\end{tabular}

\section{B-The Linguistic Analysis of Extracts (1-2) from New York Post}

The social actors are categorized as "Syrians, and immigrants from the middle east" in extract (1) and (2) Implicitly a blame has been directed to the Europiean countries since immigrants havenot got any apportunity to integrae within the society, it is adentified in extract (1):

"Europe has done a poor job of turning immigrants, especially from the Middle East, into Europeans"

Moreover a tapoi of responsibility is identified in the last part, the responsibility of Europiean countries of assimilating those immigrants. On the other hand, apresupposition is adentified in extract (2):

"the American people and our traditions of assimilating newcomers will at least lead to better lives for those Syrians"

It presupposes that Syrians are welcomed in America because American traditions helped abetter integration since they are already a nation of immigrants. Thus here atopoi of history is found here by mentioning American traditions of assimilating immigrants.

\subsubsection{Extract taken from New York Post Article (2) :}

\section{"Shouldn't we first help the Christian victims of Mideast genocide?"}

Extract (3)

"If we want to accept refugees in flight from Arab and Muslim war zones, why not start with Christians who are being slaughtered by Muslims in Muslim-majority countries? Although they're Arabs, Africans or Central Asians, the fact that they're also Christians might make them more inclined to assimilate to Western ways - and, even if they assimilate imperfectly, they're more likely to respond to Western freedoms in nonviolent ways." 
A-The Ideological Analysis of Extract (3) which is illustrated in Table (4-2) below

\begin{tabular}{|l|l|l|l|}
\hline No. & Parts Selected & \multicolumn{2}{l|}{ Macro analysis } \\
\hline 3 & $\begin{array}{l}\text { (Us) } \\
\text { "If we want to accept refugees in flight from Arab and } \\
\text { Muslim war zones, why not start with Christians who } \\
\text { are being slaughtered by Muslims in Muslim-majority } \\
\text { countries" }\end{array}$ & Christians & $\begin{array}{l}\text { Arab and Muslim, } \\
\text { refugees, } \\
\text { Christians }\end{array}$ \\
$\begin{array}{l}\text { In this part , Muslim refugees are differentiated negatively from Christians, while both are } \\
\text { victimes of terrorism. A report issued by the US National Counter terrorism Center proved that } \\
\text { Muslims accounted for } 82 \text { to 97 percent of victims of terrorist attacks in the past five years. (The } \\
\text { Independent:2016), }\end{array}$ \\
\hline
\end{tabular}

\section{B-The Linguistic Analysis of Extract (3) from New York Post}

According to actor description, there is acategorization here by using terms like "Muslim, Christians ,Arab ,and refugees". An attribute is used to describe the violent of muslims as in the line "Christians who are being slaughtered by Muslims. " On the other hand, there is a fallacy is adentified in the argumentation strategies :

"If we want to accept refugees in flight from Arab and Muslim war zones, why not start with Christians who are being slaughtered by Muslims in Muslim-majority countries".The truth is thatboth Christians and Muslims are victims of terrorism , moreover the majority of victimes are Muslims according to the report published by the US National Counterterrorism Center (The Independent:2016).

\subsubsection{Extracts taken from New York Post Article (3):}

"Trump's bid to keep Syrian refugees safe - at home"

Extract (4)

"Half of Syria's population is homeless. Its neighbors - Jordan, Lebanon and Turkey — carry most of the burden of handling the refugees.And they're exhausted. Europe is facing a populist backlash against its permissive refugee resettlement. Same here, though Obama took in just a minuscule number of Syrians to begin with."

\section{Extract (5)}

"We have in history different examples of safe zones, and some of them were tragic," new UN Secretary-General Antonio Guterres said recently. Specifically, the United Nations is traumatized by Srebrenica, a supposedly "safe” zone in Bosnia, where in one 1995 week, 8,000 Muslims were massacred as UN guards helplessly watched.Would anyone have better luck in similarly bloody Syria? Can any zone, no matter how well guarded, be completely safe? " 
A-The Ideological Analysis of Extracts (4-5) which are illustrated in Table (4-3) below

\begin{tabular}{|c|c|c|c|}
\hline \multirow[t]{2}{*}{ No. } & \multirow{2}{*}{ Parts Selected } & \multicolumn{2}{|c|}{ Macro analysis } \\
\hline & & (Us) & ( Them) \\
\hline \multirow[t]{2}{*}{4} & $\begin{array}{l}\text { "Half of Syria's population is homeless. Its neighbors- } \\
\text { Jordan, Lebanon and Turkey - carry most of the } \\
\text { burden of handling the refugees. And they're exhausted. } \\
\text { Europe is facing a populist backlash against its } \\
\text { permissive refugee resettlement. Same here, though } \\
\text { Obama took in just a minuscule number of Syrians to } \\
\text { begin with." }\end{array}$ & Europ & $\begin{array}{l}\text { Refugees, s yrian } \\
\text { s }\end{array}$ \\
\hline & \multicolumn{3}{|c|}{$\begin{array}{l}\text { Those syrian refugees are seen positively as victimes who are homeless and suffer in } \\
\text { neighbouring countries but Europ and America have apooring role in resettling them. }\end{array}$} \\
\hline \multirow[t]{2}{*}{5} & $\begin{array}{l}\text { "We have in history different examples of safe zones, } \\
\text { and some of them were tragic," ...where in one } 1995 \\
\text { week, 8,000 Muslims were massacred as UN guards } \\
\text { helplessly watchedWould anyone have better luck in } \\
\text { similarly bloody Syria? Can any zone, no matter how } \\
\text { well guarded, be completely safe?" }\end{array}$ & $\mathrm{We}$ & Syria \\
\hline & \multicolumn{3}{|c|}{$\begin{array}{l}\text { This part showesSyrian refugees positively as victimes. There is asympathic view to the } \\
\text { refugee in rejecting building safe" zones in Syria because they may be breached by } \\
\text { terrorists causingalot of victimes. }\end{array}$} \\
\hline
\end{tabular}

\section{B-The Linguistic Analysis of Extracts (4-5) from New York Post}

In this extract, there is a categorization to the social actor by using the word "Muslims". Clearly this part presupposes thatthese Syrian safe zones are not really safe and may be breached by terrorists .

In the case of argumentation strategies, a topoi of history and humanitarian are identified by telling a humanitarian story from history to arouse asympathetic views towards the Syrian refugees.

"We have in history different examples of safe zones, and some of them were tragic", "where in one 1995 week, 8,000 Muslims were massacred as UN guards helplessly watched".

\subsubsection{Extracts taken from New York Post Article (4):}

"Europe is enabling a rape culture"

\section{Extract (5)}

" More than 100 criminal complaints have been filed, 75 percent of which were reports of sexual assault. Two women reported being raped by the men, who were allegedly of North African and Arab appearance. Women in Hamburg and Stuttgart also reported similar attacks". 
A-The Ideological Analysis of Extract (5) which is illustrated in Table (4-4) below

\begin{tabular}{|l|l|l|l|}
\hline No. & Parts Selected & \multicolumn{2}{l|}{ Macro analysis } \\
\cline { 3 - 4 } & & (Us) & ( Them) \\
\hline 7 & $\begin{array}{l}\text { Mercent of which were reports of sexual assault.Two } 100 \text { criminal complaints have been filed, 75 } \\
\text { women reported being raped by the men, who were } \\
\text { allegedly of North African and Arab appearance" }\end{array}$ & M en \\
& $\begin{array}{l}\text { Negatively ,North African and Arab people represent the first group suspected in the spread of } \\
\text { sexual assaults in Germany. Syrian and Iraqi refugees are the more recent group afterGermany's } \\
\text { open door refugee policy, thus they are typically accused , while reality is otherwise. } \\
\text { According tothe federal criminal Police office of Germany (BKA) documents show that a great } \\
\text { proportion of offenses can be regarded as mere trivialities and Syrian and Iraqi migrants feature } \\
\text { relatively little in the research.( Deutsche-Welle: 2016) }\end{array}$ \\
\hline
\end{tabular}

\section{B-The Linguistic Analysis of Extract (5) from New York Post}

As for the social actor description , a categorization is used to refer to them, that is identified in the: "the men, north African and Arab"

It also presuppose that those suspected men belong to Syrian and Iraqi refugees who are the more recent group after Germany's open door refugee policy. The rhetorical devices includes the use of hyperbole for exaggeration by the use of numbers to refer to the danger of those men as in :

"More than 100 criminal complaints have been filed, 75 percent of which were reports of sexual assault"

While the argumentation strategy represented by a topoi of danger/threat is found in the same previous line that refer to the danger of those North African and Arab men on society.

\subsection{CDA of the image of Arab immigrants in the British newspaper (The Daily Express)}

This part presents a CDA of extracts of four articles chosen from the websites of the British newspaper (The Daily Express). The same procedure are followed in the analysis of the American newspaper will be followed here.

\subsubsection{Extracts taken from The Daily Express Article(1) :}

"The economic madness of mass migration laid bare"

\section{Extract (1)}

"Far from boosting the economy the numbers of non-Europeans landing on these shores increase the public sector bill by $£ 8.1$ million a day, wiping out the estimated $£ 105$ million EU migrants are thought to have contributed since 2001 by the middle of this month." 


\section{Extract (2)}

"Social services are now stretched to breaking point, there are schools where the first language is no longer English, the NHS cannot cope with the demands upon it and there is a housing shortage which is almost certain to get rapidly worse."

A-The Ideological Analysis of Extracts (1-2) which are illustrated in Table (5-1) below

\begin{tabular}{|l|l|l|l|}
\hline No. & Parts Selected & \multicolumn{2}{l|}{ Macro analysis } \\
\hline 1 & $\begin{array}{l}\text { "Far from boosting the economy the numbers of non- } \\
\text { Europeans landing on these shores increase the public } \\
\text { sector bill by } £ 8.1 \text { million a day" } \\
\text { shores (UK) }\end{array}$ & $\begin{array}{l}\text { Not European refer } \\
\text { to migrants }\end{array}$ \\
& $\begin{array}{l}\text { This part portrayed those non European migrants negatively as aburden on the British } \\
\text { economy. }\end{array}$ & Migrants \\
\hline $\mathbf{2}$ & $\begin{array}{l}\text { "Social services are now stretched to breaking point, } \\
\text { there are schools where the first language is no longer } \\
\text { English, the NHS cannot cope with the demands upon it } \\
\text { and there is a housing shortage" }\end{array}$ & \\
$\begin{array}{l}\text { Imigrants are protrayed negatively because they are accused of exhausting the Social } \\
\text { services of the their receving country. }\end{array}$ & \\
\hline
\end{tabular}

\section{B-The Linguistic Analysis of Extracts (1-2) from the Daily Express}

As for actor descriptions, it occurs in the categarization of migrants in to "non-Europeans " in extract (1). While, both topos of burdening, and finance are represented in extract (1): "the numbers of non-Europeans landing on these shores increase the public sector bill by £8.1million a day"

Mowever a topoi of burdening is identified again because migrants are accused of exhausting the social system, as in extract (2): "Social services are now stretched to breaking point, there are schools where the first language is no longer English, the NHS cannot cope with the demands upon it and there is a housing shortage"

\subsubsection{Extracts taken from The Daily Express Article (2):}

\section{"Several Iraqi men arrested over sexual assaults in Berlin"}

\section{$\operatorname{Extract(3)}$}

"SEVERAL Iraqi men have been arrested on suspicion of sexually assaulting a number of women in Berlin in the early hours of this morning, prompting German police to launch an investigation and appeal for witnesses. " 
Extract (4)

"This is the latest in a series of sex assaults involving migrants, which have fuelled increasing anger in recent months over Germany's open door refugee policy. In the most notorious incident, hundreds of women were targeted by marauding gangs of men, many of them migrants, in Cologne last New Year's Eve. "

A-The Ideological Analysis of Extract (3-4) which is illustrated in Table (5-2) below

\begin{tabular}{|c|c|c|c|}
\hline \multirow[t]{2}{*}{ No. } & \multirow[t]{2}{*}{ Parts Selected } & \multicolumn{2}{|l|}{ Macro analysis } \\
\hline & & (Us) & ( Them) \\
\hline \multirow[t]{2}{*}{5} & $\begin{array}{l}\text { "SEVERAL Iraqi men have been arrested on suspicion } \\
\text { of sexually assaulting a number of women in Berlin in } \\
\text { the early hours of this morning, prompting German } \\
\text { police to launch an investigation and appeal for } \\
\text { witnesses". }\end{array}$ & $\begin{array}{l}\text { number } \\
\text { women } \\
\text { Berlin }\end{array}$ & $\begin{array}{l}\text { SEVERAL Iraqi } \\
\text { men }\end{array}$ \\
\hline & \multicolumn{3}{|c|}{$\begin{array}{l}\text { Those iraqi migrants are portrayed negatively as sextual assaults while there is no evidence } \\
\text { at all about them. }\end{array}$} \\
\hline \multirow[t]{2}{*}{6} & $\begin{array}{l}\text { "This is the latest in a series of sex assaults involving } \\
\text { migrants, which have fuelled increasing anger in recent } \\
\text { months over Germany's open door refugee policy" }\end{array}$ & Germany & $\begin{array}{l}\text { oigrants } \\
\text { (Several Iraqi men) }\end{array}$ \\
\hline & \multicolumn{3}{|c|}{$\begin{array}{l}\text { Negatively, this part refers to several Iraqis who are potrayedas sexual assaults, while } \\
\text { they have been released because there is no evidence against them. There is ageneral } \\
\text { accusition to syrian and iraqi refugees who are typically the first groups suspected in any } \\
\text { criminal investigation in germany since they are the more recent group afterGermany's } \\
\text { open door refugee policy.The Federal Criminal Police Office of Germany BKA proved that } \\
\text { agreat proportion of offenses can be regarded as mere trivialities and syrian and iraqi } \\
\text { migrants feature relatively little in the research.( Deutsche-Welle: 2016) } \\
\text { The terms migrants and refugee are used interchangeably in this extract while the } \\
\text { distinction is important. Countries deal with refugees through refugee and aslyum norms, } \\
\text { while migrants are treated according to goverments laws (UNHCR:2016). }\end{array}$} \\
\hline
\end{tabular}

\section{B-The Linguistic Analysis of Extract (5-6) from the Daily Express}

These extracts include actors categorization, adentified in the terms :

" migrants , and several Iraqi men". They are represented as adanger on society through the topoi of danger , that is adentified in the attributes : "have been arrested on suspicion of sexually assaulting a number of women in Berlin", "This is the latest in a series of sex assaults involving migrants. "

These lines above presuppose that iraqi and syrian refugees are typically the first groups suspected in a criminal investigations in Germany since they are the more recent group after Germany's open door refugee policy.

Afallacy is also adentified here regarding the claim that Syrian and Iraqi refugees are responsible for these series of sex assaults in Germany because there is no evidence is given at all for such aclaim .

Hence, Confidential BKA documents proved that agreat proportion of offenses can be regarded as mere trivialities and 
syrian and iraqi migrants feature relatively little in the research ,but those who found guilty are those from balkans.( Deutsche-Welle: 2016)

\subsubsection{Extracts taken from The Daily Express Article (3):}

\section{"Flood of illegal migrants highlights border fiasco - EXPRESS COMMENT"}

\section{Extract (7)}

"But this must be stopped right now. The overpowering motive behind this country voting for Brexit was to cut back the number of immigrants entering this country - and they were the legal ones, citizens of the EU. But these figures refer to people we know little about, with very different values from our own. "

\section{Extract (8)}

"And it is a disgrace that in this age of increased terrorist attacks people who may wish us harm have not only been able to evade border security but now will be at liberty to live out the rest of their lives in this country. As David Wood, who presented the report said, there must be consequences and in the case of illegal immigration this means deportation".

A-The Ideological Analysis of Extracts (7-8) which are illustrated in Table (5-3) below

\begin{tabular}{|c|c|c|c|}
\hline \multirow[t]{2}{*}{ No. } & \multirow[t]{2}{*}{ Parts Selected } & \multicolumn{2}{|l|}{ Macro analysis } \\
\hline & & (Us) & ( Them) \\
\hline \multirow[t]{2}{*}{7} & $\begin{array}{l}\text { "But this must be stopped right now. The overpowering } \\
\text { motive behind this country voting for Brexit was to cut } \\
\text { back the number of immigrants entering this country - } \\
\text { and they were the legal ones, citizens of the EU, But } \\
\text { these figures refer to people we know little about, with } \\
\text { very different values from our own" }\end{array}$ & $\begin{array}{l}\text { We } \\
\text { to refer to } \\
\text { british society }\end{array}$ & $\begin{array}{l}\text { Immigrants, people } \\
\text { we know little } \\
\text { about }\end{array}$ \\
\hline & \multicolumn{3}{|c|}{$\begin{array}{l}\text { In this part ,immigrants who are non-Europeans are portrayed negatively as illegal ones } \\
\text { who come from different cultures. Basically, They are portrayed as peoples whose norms } \\
\text { violate the British values and morals. }\end{array}$} \\
\hline \multirow[t]{2}{*}{8} & $\begin{array}{l}\text { "And it is a disgrace that in this age of increased } \\
\text { terrorist attacks people who may wish us harm have not } \\
\text { only been able to evade border security but now will be } \\
\text { at liberty to live out the rest of their lives in this country" }\end{array}$ & in this country & people \\
\hline & \multicolumn{3}{|c|}{$\begin{array}{l}\text { According to these lines, those migrants are generally portrayed negatively because they } \\
\text { cause feeling of threat to British people. The majority of migrants who entered Uk are } \\
\text { refugees who are actually victims fleeing terrorist attacks and wars in their countries. }\end{array}$} \\
\hline
\end{tabular}

\section{B-The Linguistic Analysis of Extracts (7-8) from the Daily Express}

The actors represented here by the categorizing term "immigrants". Under the umberlla of topos of culture,immigrants are portrayed as those people who are from another cultures that may change their norms 
" they were the legal ones, citizens of the EU,But these figures refer to people we know little about, with very different values from our own"

Mentioning the term legal in the last line for European citizens presuppose that those immigrants are illegal .

There is a topoi of danger/threat is adentified in the description for immigrants as danger on their safety presupposing criminal attacks may be happened because of them, as in:

" people who may wish us harm have not only been able to evade border security"

\subsubsection{Extracts taken from The Daily Express Article(4) :}

\section{"The Tories must get a grip on immigration now, says LEO McKINSTRY"}

\section{Extract (9)}

"According to the latest report from the Office for National Statistics, just 38 percent of migrants who settled here in the last year were actually looking for work."

\section{Extract (10)}

"On the contrary, it undermines social cohesion, stretches public services to breaking point, creates housing shortages, and weakens national solidarity. "

A-The Ideological Analysis of Extracts (9-10) which are illustrated in Table (5-4) below

\begin{tabular}{|c|c|c|c|}
\hline \multirow[t]{2}{*}{ No. } & \multirow[t]{2}{*}{ Parts Selected } & \multicolumn{2}{|c|}{ Macro analysis } \\
\hline & & (Us) & ( Them) \\
\hline \multirow[t]{2}{*}{9} & $\begin{array}{l}\text { "just } 38 \text { percent of migrants who settled here in the last } \\
\text { year were actually looking for work. " }\end{array}$ & UK & $\begin{array}{l}\text { migrants refer to } \\
\text { non-EU migrants }\end{array}$ \\
\hline & \multicolumn{3}{|c|}{$\begin{array}{l}\text { This persentage showes immigrants negatively as lazy people who depend on charities and } \\
\text { burden the economy. The term migrants used to describe those people who arrived in } 2017 \\
\text { while they are actually identified as granted refugee status . Such distinction is important } \\
\text { because countries deal with them through refugee and aslyum norms .(UNHCR:2016) }\end{array}$} \\
\hline \multirow[t]{2}{*}{10} & $\begin{array}{l}\text { "it undermines social cohesion, stretches public services } \\
\text { to breaking point, creates housing shortages, and } \\
\text { weakens national solidarity." }\end{array}$ & British people & $\begin{array}{l}\text { migrants refer to } \\
\text { non-EUmigrants }\end{array}$ \\
\hline & \multicolumn{3}{|c|}{$\begin{array}{l}\text { Immigrants negatively are described as leading causes of anxiety, and they represent a } \\
\text { danger to community relationsand national solidarity. In addition to their stress on social } \\
\text { services. }\end{array}$} \\
\hline
\end{tabular}

\section{B-The Linguistic Analysis of Extracts (9-10) from the Daily Express}

The term "migrants" is used as a actor categorization the social actors here. These extract are full of topos .Topos of authority and numbers and burdening are used to represent these migrants as in extract (9)

"According to the latest report from the Office for National Statistics, just 38 percent of migrants who settled here in the last year were actually looking for work." 
Topoi of burdening are used again in extract (10) to show those migrants as aburden on the social system as in:

"On the contrary, it undermines social cohesion, stretches public services to breaking point, creates housing shortages, and weakens national solidarity".

This extract presuposes that those migrants are different and dont have ability to integrate within the british community

\subsection{Findings}

All the selected extracts from the articles of New york post and Daily express have been analyzed in the same manner and the findings of this analysis that are presented in the tables below. Tables (1) the ideological categories of macro analysis in the selected American and British articles .Generally speaking, the discourse of British articles is found to be greatly loaded with racist ideologies .

British articles show the negative side of "Them" which is all about representing immigrants negatively that appears in $100 \%$ of British articles. This, in turn has verified the findings of Khosravinik (2014: 518) study of British press and Bennet .,et al (2015:15) content analysis of "Refugee and Migrant Crisis" in the EU .They found that most of British newspapers portrayed immigrants negatively .

The statistical results assert that just $50 \%$ of American articles reflect negative Other representations while $50 \%$ show positive representations. It is worth mentioning that American articles are less racist than British articles towards immigrants since America is a nation of immigrants. This, in turn has violated the third hypothesis of the present study, that reads: The American and British newspapers under investigation employ the same representations in portraying the image of Arab immigrants.

\section{The ideological categories of macro analysis in American \\ and British articles : Table (1)}

\begin{tabular}{|l|l|l|}
\hline Ideological categories & w york post No. \& \% & ily express No. \& \% \\
\hline Us vs. Them & $50 \%$ & $100 \%$ \\
\hline Negative other presentation & $50 \%$ & $100 \%$ \\
\hline Presentation & $50 \%$ & $0 \%$ \\
\hline
\end{tabular}




\section{REFERENCES}

Al Wekhian, J.( 2015). Conflict Behaviors: Religiosity, Culture, and Gender as Predictors for Conflict Management Styles Among First and Second Generation Arab Muslim Immigrants in the United States Kennesaw State

Al-Azzawi , M.(2018) .Critical Discourse Analysis of the Arab Spring Reflections on Arab Muslims Image in Selected Western Newspapers .Ph.D. Thesis Submitted to The Collage of Arts in Baghdad.

Blackledge, A .(2005). The legitimation of Discriminatory Discourse and Power in a Multilingual World. University of Birmingham John Benjamins Publishing Company Amsterdam/Philadelphia

Breeze , $\mathrm{R}$ (2011) CRITICAL DISCOURSE ANALYSIS AND ITS CRITICS :21:4.493-525 Pragmatics International Pragmatics Association .DOI: Estevens,J .(2018).Migration crisis in the EU: developing a framework for analysis of national security and defense strategies NOVA University of Lisbon \& IPRI-NOVA.

Fairclough, N. (1995).Critical Discourse Analysis':The Critical Study of Language. London :Longman group.

Fowler, R. (1996) Linguistic Criticism. 2nd ed. British: Oxford University Press.

Global Terrorism Index(2016) A Center of Excellence of the U.S. Department of Homeland Security Led by the University of Maryland

Hanak,I.( 2009). Language ,Discourse and Participation :Studies in Donnor-driven Development in Tanzania . Berline :Lit Verlage Fresnostr

Hassan , A.(2017). A Critical Discourse Analysis of Iraqi Immigrants' Image in Selected English and Arabic News Channels Thesis University of Baghdad in .

Hassan,A\& Al-Zubaidi,N.(2018)Discriminatory and Racist Discourse in American TV Channels: The Image of Arab Immigrants .Journal of Education in Black Sea Region, Vol. 4, Issue 1.

Hodge, R \& Kress, G. (1993). Language as Ideology . $\left(2^{\text {nd }}\right.$ ed.). London : Routledge

International Organization for Migration.(2019) Key Migration Terms 7 Route des Morillons 1218 GrandSaconnexSwitzerland

Te+41.22.717.9111https://www.iom.int/key-migration- terms.

Khan ,A (2003). Islam, Muslims, and America: Understanding the Basis of their Conflict . New York :Algora Publishing .

Leeuwen ,V.( 2013) Text and Practices : Readings in Critical Discourse Analysis, Edited by C. Caldas, C.Coulthard and M. Coulthard .London:Taylor \&Francies Library.

Lester , J \& Paulsen , J.( 2018) . Language-Based Methodologies for Policy and Leadership Research in "Complementary Research Methods for Educational Leadership and Policy Studies.Lochmiller , Chad (Ed).USA: Library of Congress

Machin, D.,\&Mayr A. (2012). How to docritical discourse analysis: A Multimodal Introduction. Los Angeles: SAGE.

Moody, M. (2008). Black and Mainstream Press' Framing of Racial Profiling: A Historical Perspective . America :University Press of America.

Nordquist, R. (2019). What Does Argumentation Mean? Retrieved from https://www.thoughtco.com/what-is-argumentation1689133.

Nowrasteh,A .(2017). The Use of Euphemisms in Political Debate . Retrieved from.https://www.cato.org/blog/use-euphemismspolitical-debate

Paltridge,B.(2012) "Discourse Analysis ": Introduction,Edited by K.Hyland,2nd ed. London: Routledge.

Rahimi,A.\&Sahragard,R.(2006) “ Critical Discourse Analysis".Iran :Shiraz University Press.

Reisigl,M \& Wodak , R .(2009). The DiscourseHistorical Approach in Methods of Critical Discourse Analysis, second edition SAGE .

Shaban,S.(2018)Power and Ideology in ISIS Radicalization Messages: A Critical Discourse Analysis A Thesis Submitted to The Council of The College of Arts Mustansiryah

Smedley ,A .(2017) .Racism . Published Encyclopedia Britannica, In https://www.britannica.com/topic/racism. UNHCR (2015) The sea route to Europe: The Mediterranean passage in the age of refugees. Available at :http://www.unhcr.org/5592bd059.html University of Amsterdamat Pompeu Fabra, Barcelona. Version 1.0. 
Van Dijk, T.A. (2001b) “Critical Discourse Analysis". In The Handbook of Discourse Analysis, Edited by D. Tannen, D. Schiffrin and H. Hamilton . Oxford: Blackwell.

Van Dijk, T.A. (2002). Ideologies, Racism, Discourse: Debates on Immigration and Ethnic Issues . In Comparative Perspectives on Racism . Aldershot etc. :Amsterdam Center for Language and Communication . Van Dijk, T.A. (2000a). Ideology and discourse: a multidisciplinary introduction. Pompeu Fabra University: Barcelona

Van Dijk, T.A.(2004). Politics, ideology and discourse. Encyclopedia of language and Politics.

Weiss,G.\&Wodak,R.(2003).Critical Discourse

Analysis:

theory
interdisciplinary,Basingstoke:Palgrave.

Wodak, R. (2001) "What CDA is About". In Methods of Critical Discourse Analysis, Edited by R. Wodak and M. Meyer,pp. 1-12. London: Sage.

Wodak, R., \& van Dijk, T.A. (2000). Racism at the top, Drava, Austrian Ministry of Education, Science and Culture, Austria.

Wodak,R .(2001).'The Discourse-Historical Approach". In Methods of Critical Discourse Analysis, Edited by R. Wodak and M. Meyer. London: Sage.

Wodak,R .(2017) .Strangers in Europe in A DiscourseHistorical Approach to the Legitimation of Immigration Control 2015/16 15032-0577d-1Pass-r04.indd 3122 06-2017

$13: 47: 34$. 